
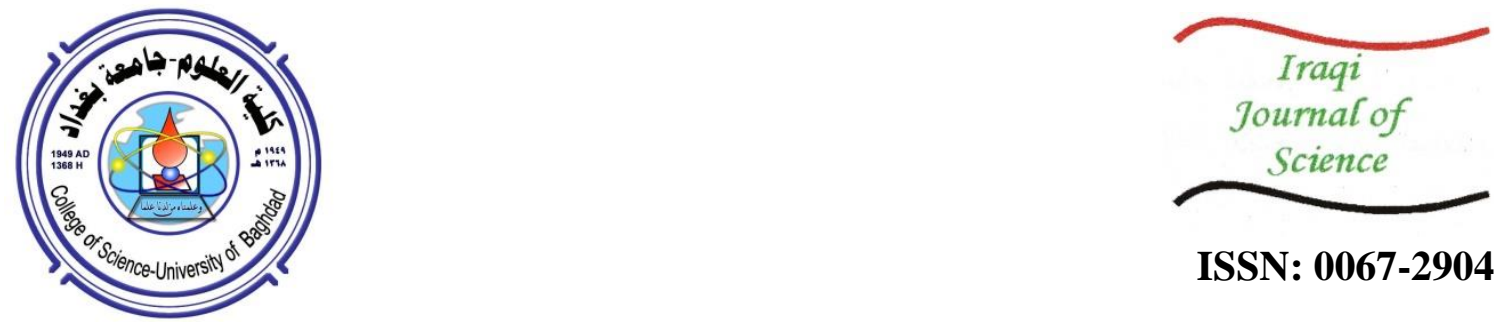

ISSN: 0067-2904

\title{
Production of Aspartame by Immobilized Thermolysin
}

\author{
Mohammed A. Alsoufi ${ }^{1 *}$, Raghad A. Aziz ${ }^{2}$ \\ ${ }^{1}$ Department of Evaluating Products, Market Research and Consumer Protection Centre, University of Baghdad, \\ Baghdad, Iraq \\ ${ }^{2}$ Department of Science, College of Basic Education, University of Al-Mustansiriah, Baghdad, Iraq
}

\begin{abstract}
The aim of this study was the production of aspartame by using immobilized thermolysin in bentonite clay. The yield of immobilized thermolysin in bentonite was $92 \%$ of the original enzyme amount. $\mathrm{pH}$ profile of free and immobilized enzyme was 7.0 and 7.5 respectively which was stable at $6.5-9.0$ for $30 \mathrm{~min}$. The optimum temperature of both enzymes was $50^{\circ} \mathrm{C}$, while they were stable at $65^{\circ} \mathrm{C}$ for 30min. however, they lost 52.73 and $61.72 \%$ from its main activity at $80^{\circ} \mathrm{C}$ respectively. Immobilized thermolysin has retained all activity within 27 days, but it kept $68.27 \%$ of initial activity when stored for 60 days at $4^{\circ} \mathrm{C}$ whereas, it retained a full activity after 20 continue usage. In addition, it retained $86.53 \%$ of its original activity after 30 continuing usages. The yield of produced aspartame was increased with reaction time; it was $9 \%$ after $1 \mathrm{~h}$ and increased gradually to $100 \%$ after $10 \mathrm{~h}$ at reaction conditions.
\end{abstract}

Keywords: Immobilized enzymes, Thermolysin, Bentonite, Aspartame precursor, Enzymes applications.

\section{إنتاج سكر الأسبارتام باستعمال أنزيم Thermolysin المقيد}

\author{
محمه عبد الرزلق الصوفي 1*2، رغد أكرم عزيز2

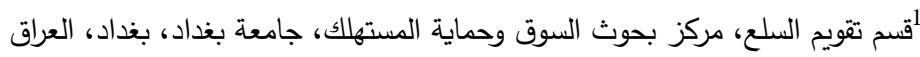

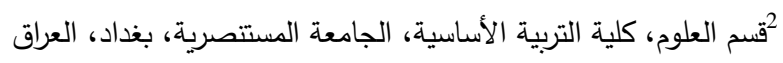

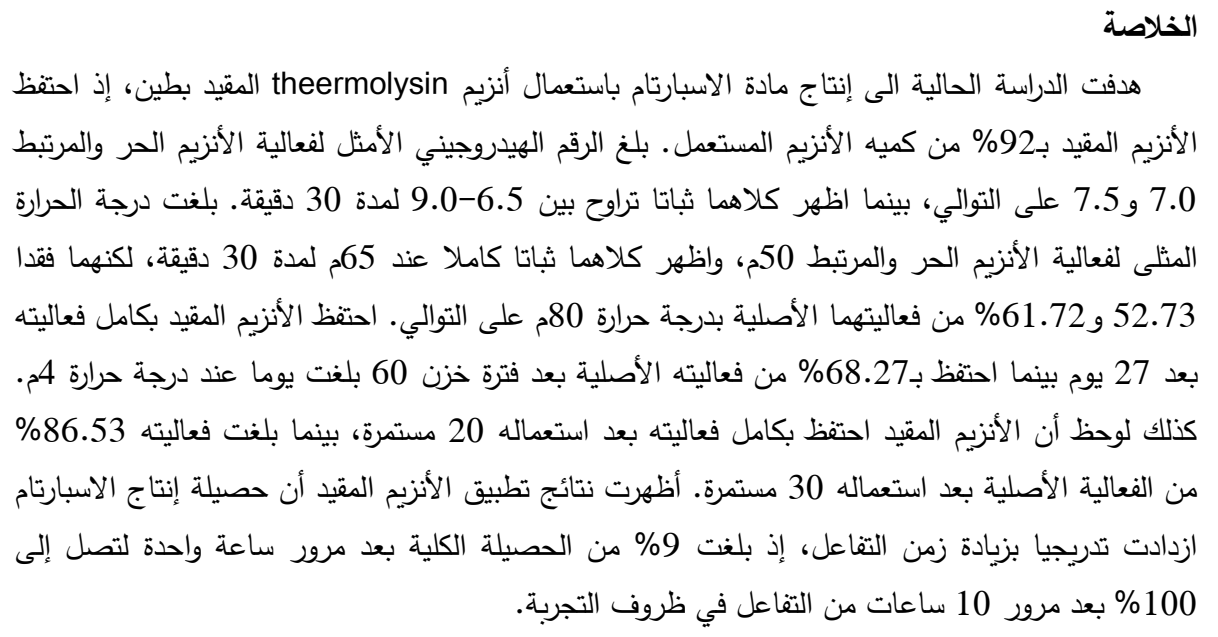

*Email: alsoufim@mracpc.uobaghdad.edu.iq 


\section{Introduction}

Thermolysin (EC 3.4.24.27) is considered a thermostable and zinc-dependent neutral metalloproteinase, which is present in bacterial sources [1], and work as a catalyst for hydrolysis or synthesis of peptide bonds [2], therefore, it used widely to bioactive peptides produce during formation of bond or hydrolysis of protein [3], thermolysin has a high specific action against of amino acids which contain bulky and hydrophobic side chains [4], so, the most using of thermolysine include peptide preparation of N-carbobenzoxy L-Asp-L-Phe methyl ester (ZDFM) by coupling, Ncarbobenzoxy L-Asp (ZD) and L-Phe methyl ester (PM) to formation a precursor which consider as a starter to artificial sweetener production [5]. Aspartame its combining of aspartic acid and phenylalanine which discovered in 1969 as sweetener that has "sweetening up to 200 times more than to table sugar with $4 \mathrm{kcal} / \mathrm{g}$ which use in many consumer products [6], such as tabletop sweeteners, yogurt, chewable multi vitamins, soft drinks, breakfast cereals and pharmaceuticals [7], due to its good sensory properties, such as, safety to high temperature, non carcinogenic and acceptable from consumer [8].

Immobilized enzymes were used in many industrial applications, such as, foods, pharmaceuticals, detergents and textile [9], this technique provides several advantages for enzymes, such as, improving catalytic properties, reducing of production cost, possibility of using them more than once and the promote and increase stability $[10,11]$. Several methods have been reports to immobilization of thermolysin, such as, covalent, adsorption and other methods [5], covalent linkage of enzymes with immobilizing material happen to "side chain amino acids, such as, aspartic acid, arginine, and histidine, the degree of reactivity depended on functional groups, such as, phenolic hydroxyl, imidazole, indolyl, etc. [12, 13].

Bentonite clay (Montmorillonite) is known as the most popular clay rocks in the world that widely used as a support in different applications, the nature of this clay was acidic which provide acid sites for adsorption of enzymes through $\mathrm{NH}_{2}$ group [9]; the clay also, can be activated with glutaraldehyde to make covalent bond with enzyme [13]. Due to republic of Iraq possession a huge quantity of this clay in the Western regions, so, the aim of this study was to use bentonite as a substance to immobilize thermolysin and study some effects of its activity and its application for aspartame precursor production.

\section{Materials and methods}

\section{Chemicals}

Lyophilized powder of thermolysin from Geobacillus stearothermophilus (Sigma-Aldrich), Bentonite, was obtained from local market in Baghdad.

\section{Thermolysin assay}

Azocasein was used as a substrate for free and immobilized thermolysin activity. $4 \mathrm{~mL}$ of $(0.5 \%)$ substrate solution was mixed with enzyme solution $(2 \mathrm{~g} / \mathrm{L}$ of thermolysin in $50 \mathrm{mM}$ phosphate buffer at $\mathrm{pH}$ 7.0), and the reaction was continued until proteolysis of the casein releasing a soluble dye into solution. The reaction was stopped by adding $500 \mu \mathrm{L}$ of $15 \%$ trichloroacetic acid to a $1 \mathrm{~mL}$ aliquot of the reaction solution, then centrifugation at $10000 \mathrm{rpm}$ for $15 \mathrm{~min}$. The precipitate was removed and enzymatic activity was measured at $440 \mathrm{~nm}$. One unit of enzymatic activity was defined as an amount of thermolysin producing an increase of 0.1 absorbance units/min at 440nm [2, 3]

$$
\text { Units } / \mathrm{ml} \text { enzyme }=\frac{\Delta \mathrm{A} 440 \mathrm{~nm} \text { Sample } \times \mathrm{T} . \mathrm{V}}{\mathrm{T} \times \mathrm{V}}
$$

$\Delta$ A440nm Sample $=$ A440nm Test - A440nm Sample Blank

TV $=$ Total volume (in milliliters) of assay

$T=$ Time of assay (in minutes) as per the Unit Definition

$\mathrm{V}=$ volume of enzyme (in milliliter) of enzyme used

\section{Protein estimation}

Protein $(\mathrm{mg} / \mathrm{ml})$ was estimated through a method of Bradford [14].

\section{Activation of bentonite clay}

Bentonite was activated by stirring with $10 \%$ of 3-APTES solution in acetone (v/v) for $1 \mathrm{~h}$ at room temperature. The mixture was then filtered, washed with acetone and dried at $80^{\circ} \mathrm{C}$. Then the mixture was treated with $10 \%$ aqueous glutaraldehyde solution (v/v) for $1 \mathrm{~h}$ and filtered, washed, dried at $25^{\circ} \mathrm{C}$ and stored in $20 \mathrm{mM}$ phosphate buffer $\mathrm{pH} 7.0$ at $4^{\circ} \mathrm{C}$ until use [13]. 


\section{Immobilization of thermolysin:}

Twenty $\mathrm{mL}$ of enzyme solution $(2 \mathrm{~g} / \mathrm{L}$ thermolysin in $50 \mathrm{mM}$ phosphate buffer at $\mathrm{pH} 7.0)$ was mixed with $500 \mathrm{mg}$ of bentonite clay and stirred at $4^{\circ} \mathrm{C}$ for $12 \mathrm{~h}$; then centrifuged at $10000 \mathrm{rpm}$ for $10 \mathrm{~min}$. The supernatant (free enzyme) was removal and precipitate (immobilize enzyme) was washed three times with $20 \mathrm{~mL}$ of $100 \mathrm{mM}$ phosphate buffer $\mathrm{pH} 7.0$; centrifuge was used after each wash to ensure removal all free enzyme. The immobilized enzyme was stored in $20 \mathrm{mM}$ phosphate buffer $\mathrm{pH} 7.0$ at $4^{\circ} \mathrm{C}$ until use [2].

\section{Immobilization yield}

Immobilization yield was estimated by measuring the ratios of free thermolysine solution which added to bentonite $\left(\mathrm{At}_{0}\right)$ and the ratio of immobilized enzyme in bentonite after stirring the mixture at $4^{\circ} \mathrm{C}$ for $24 \mathrm{~h}$ (Att). The immobilization yield (IY) was calculated with the following equation [11].

\section{Characterization of enzyme}

$$
\mathrm{IY}(\%)=\frac{\mathrm{At}_{0}-\mathrm{Att}}{\mathrm{At}_{0}} \times 100
$$

\section{Effect of $\mathrm{pH}$ on free and immobilized thermolysin activity}

The effect of $\mathrm{pH}$ on the activity of the free and immobilized thermolysin was determined by preparing substrate (buffer containing $0.5 \%$ azocasein) in different buffer solutions include $50 \mathrm{mM}$ sodium acetate buffer, $50 \mathrm{mM}$ sodium phosphate buffer, $50 \mathrm{mM}$ Tris/ $\mathrm{HCl}$ buffer and $50 \mathrm{mM}$ Tris-base buffer to obtain ( $\mathrm{pH} 5,5.5,6,6.5,7,7.5,8,8.5$ and 9). Free and immobilized thermolysin activity was determined at $37^{\circ} \mathrm{C}$ by using $0.5 \mathrm{ml}$ and $10 \mathrm{mg}$ and the activity was measured according to the method described by [15].

\section{Effect of $\mathbf{p H}$ on free and immobilized thermolysin stability}

An equal amount (v/v) and (w/v) from free and immobilized enzyme were mixed with the buffers at different $\mathrm{pH}(5-9)$ at a ratio of $(1: 1)$ and the mixture was incubated in a water bath for $30 \mathrm{~min}$ at $37^{\circ} \mathrm{C}$. Then the samples were transferred directly to the ice bath. The remaining activity (\%) was estimated by Al-Soufi (9).

\section{Optimum temperature on free and immobilized thermolysin activity}

Free and immobilized thermolysin activity was estimated at a different range of temperature ranging from 30 to $80^{\circ} \mathrm{C}$ using $50 \mathrm{mM}$ Tris/ $\mathrm{HCl}$ buffer solution in $\mathrm{pH} 7.5$ for $10 \mathrm{~min}$ [15].

\section{Effect of temperature on free and immobilized enzyme stability}

Immobilized thermolysin was incubated at different temperatures $(30-80)^{\circ} \mathrm{C}$ for $30 \mathrm{~min}$. Followed by incubation in ice bath. Remaining activity (\%) of immobilized thermolysin was estimated by $\mathrm{Al}-$ Soufi [9].

\section{Synthetic aspartame precursor}

Immobilized thermolysine was equilibrated with $0.05 \mathrm{M}$ MES-NaOH buffer containing $5 \mathrm{mM} \mathrm{CaCl}_{2}$ in $\mathrm{pH} 7.5$ to synthetic aspartame precursor. $2 \mathrm{~g} / 100 \mathrm{~mL}$ of immobilized enzyme was added to $10 \mathrm{mLof}$ solvents mixture [tert-amyl alcohol (TA) and ethyl acetate (EA)] at various ratios, containing $40 \mathrm{mM}$ of Z-Asp and $200 \mathrm{mM}$ of PheOMe as the substrate. The reaction was left for $10 \mathrm{~h}$ at $40^{\circ} \mathrm{C}$ and the absorbance was estimated at $254 \mathrm{~nm}[16,17]$, the yield of aspartame precursor forming [N-(B enzyloxycarbony1)-L-aspartyl-L-phenylalaninme ethyl ester (Z-AspPheOMe)] (\%) was calculated as the following equation:

$$
\text { Yield }(\%)=\frac{\mathrm{A}}{\mathrm{B}} \times 100
$$

A = absorbance at $254 \mathrm{~nm}$ of reaction at hour.

B = absorbance at $254 \mathrm{~nm}$ of reaction at 10 hour.

\section{Results and discussion}

\section{Yield of immobilization}

The yield of immobilized thermolysin with bentonite was $92 \%$ from the original enzyme amount, which was largely encouraging to be used in this work. This result is similar to what reported by Moeschel et al. [18] who referred that all type of spacers and activation reagents gave high yields of immobilized thermolysin on polyamide nonwoven materials. However, in contrast, Mateo et al. [19] found that recovered activities and stabilization factors was $100 \%$ for immobilized thermolysin on glyoxyl agarose. Chen et al. [5] reported that $93.2 \%$ of thermolysin was linked to the sodium chloride 
which uses as a immobilize material, while, it was more than David et al. [2] who referred that maximum loading of Immobilization was $733 \pm 13 \mathrm{mg}$ thermolysin per $1000 \mathrm{mg}$ of glutaraldehydeactivated silica gel GA-N-CSMG. Therefore, it can be said that the high loading capacity of the bentonite will allow linking high amount of enzyme units, which lead to use of minimum immobilized thermolysin for production of aspartame.

\section{Characterization of enzyme}

\section{Optimum pH of activity and stability of free and immobilized thermolysin}

The $\mathrm{pH}$ profile of free and immobilized thermolysin activity was 7.0 and 7.5 respectively (Figure1), and both enzymes were stable at $\mathrm{pH}$ range 6.5-9.0 for $30 \mathrm{~min}$ (Figure-2).

Optimum $\mathrm{pH}$ profile of enzymes was considered as an important parameter of immobilization. The variation of $\mathrm{pH}$ value may cause inability to use immobilized enzyme in high efficiency, so, the feasibility of immobilization will be ended, and the use of free enzyme will be best $[11,13]$.

Many authors have reported this effect, such as Yun [20] who referred that the optimum pH for free and immobilize thermolysin on Dowex MWA-1 with $10 \%$ glutaraldehyde and incorporated into a fluidized bed was 8.0 and 7.0 respectively, and the immobilized enzyme was stable more than free enzyme at alkaline ph. Similarly, Moeschel et al. [18] noted that immobilized thermolysin by polyamide nonwoven materials showed a remarkable improved stability with respect to elevated extreme $\mathrm{pH}$ values. On the other hand, David [15] explained that $\mathrm{pH}$ activity profiles for free and immobilized thermolysin on nanoporous silica gel were showed maximum activity at $\mathrm{pH}$ 7.0, while David et al. [2] found that maximum $\mathrm{pH}$ activity of free and Immobilization thermolysin with glutaraldehyde-activated silica gel was 7.5.

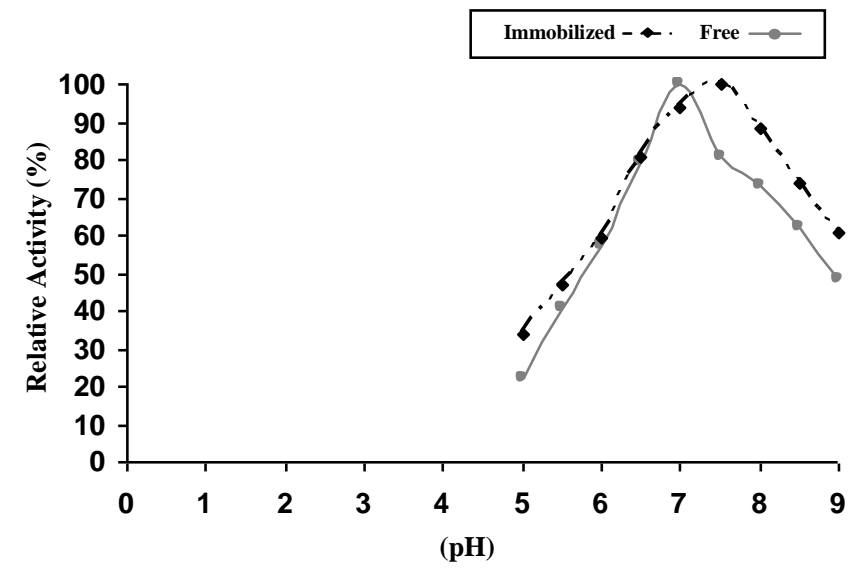

Figure 1- Effect of $\mathrm{pH}$ on activity of free and immobilized thermolysin on bentonite

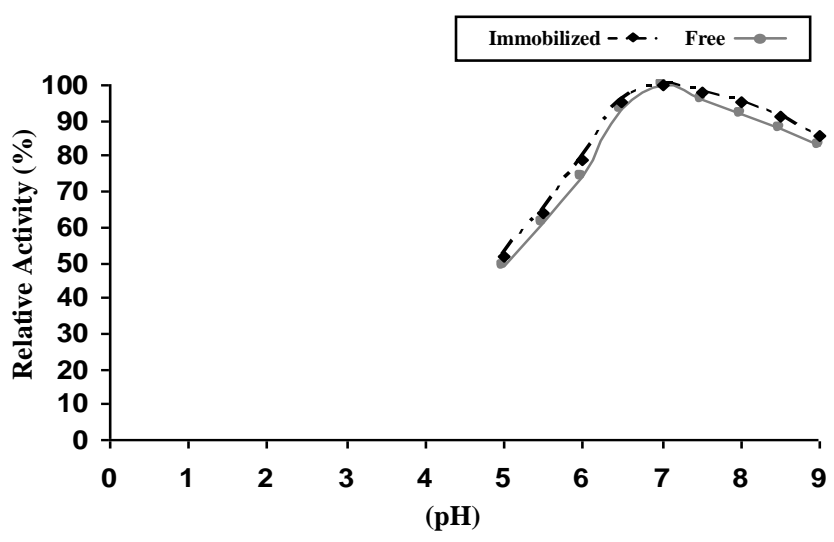

Figure 2- Effect of $\mathrm{pH}$ on stability of free and immobilized thermolysin on bentonite.

\section{Optimum temperature of activity and stability of free and immobilized thermolysin}

Optimum temperature for free and immobilized thermolysin activity was $50^{\circ} \mathrm{C}$ (Figure-3). Both enzymes were stable at $65^{\circ} \mathrm{C}$ for $30 \mathrm{~min}$, but they lost 61.72 and $52.73 \%$ respectively, from its initial activity at $80^{\circ} \mathrm{C}$ at the same time (Figure-4). 
High temperature causes a decrease in enzyme activity as a result of thermal denaturing due to the effect on open folds of the enzyme molecule and exposure of content from amino acids to the reaction medium [11]. Though, most immobilization studies were referring to a significant improve thermal stability for immobilized thermolysin with different materials [18, 5], On this basis, Yun [20] found that the optimum temperature of free and immobilize thermolysin on Dowex MWA-1 with 10\% glutaraldehyde and incorporated into a fluidized bed was 70 and $80^{\circ} \mathrm{C}$ respectively. The immobilized enzyme was stable more than free enzyme at high temperature, while, David et al. [2] referred that the free enzyme showed an increase in its activity up to $65^{\circ} \mathrm{C}$. Whereas, the immobilized thermolysin with glutaraldehyde-activated silica gel showed a huge increase in its activity up to $85^{\circ} \mathrm{C}$

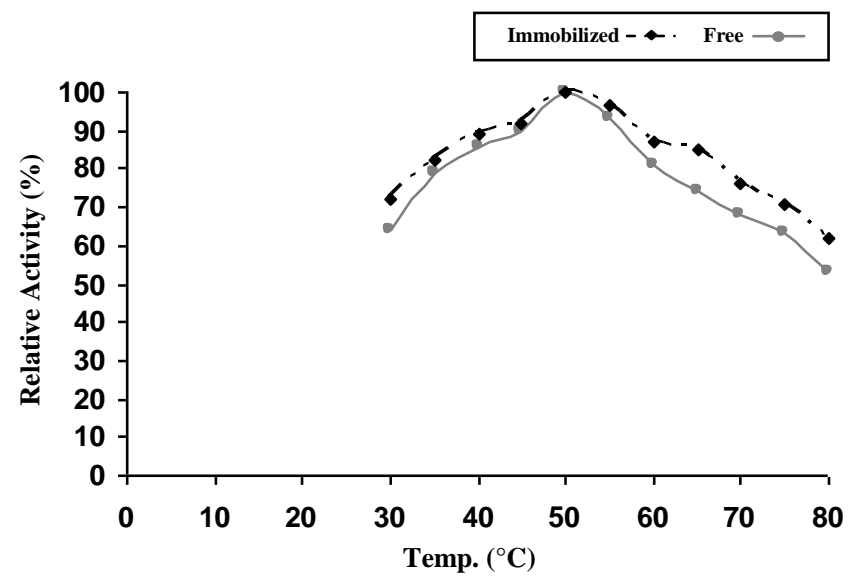

Figure 3- Effect of temperature on activity of free and immobilized thermolysin on bentonite.

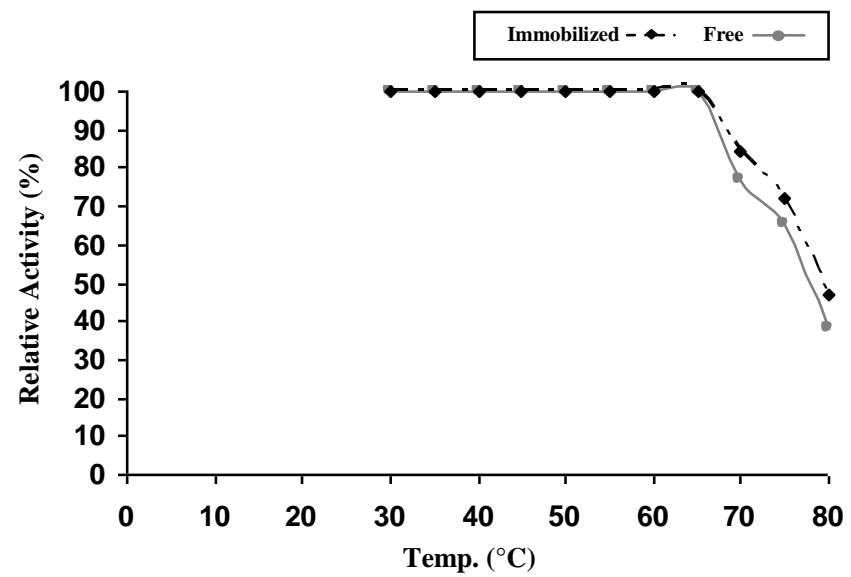

Figure 4- Effect of temperature on stability of free and immobilized thermolysin on bentonite.

\section{Storage and Reuse of immobilized thermolysin}

Immobilized thermolysin kept its activity for 27 days, but it kept $68.27 \%$ from initial activity after storage for 60 days at $4^{\circ} \mathrm{C}$ (Figure-5). It retained a full activity for 20 continue usage; while it retained $86.53 \%$ of its original activity after 30 continue usage (Figure-6).

The Storage stability and reuse of immobilized enzymes represent one of the main economic factors in the immobilization because it gives a clear conception about the efficiency of materials which are used for this purpose [11].

In this context, Persichetti et al. [21] observed that crystals of thermolysin which immobilized by cross-linked method was stable in terms of activity for several hundred hours with a very low enzyme consumption rate. The soluble thermolysin lost $50 \%$ of its activity when it stored in a mixed aqueous organic solution within the first day of incubation, but then it remains relatively stable for the next 15day. Likewise, Belyaeva et al. [22] found that the immobilized thermolysin on polyvinyl alcohol cryogel was retained about $95 \%$ of original activity after 4 months of storage in $0.05 \mathrm{M}$ Tris- $\mathrm{HCl}$ buffer that containing $50 \mathrm{mM} \mathrm{CaCl}, \mathrm{pH} 7.2$ at $4^{\circ} \mathrm{C}$. Whereas, Dridi et al. [23, 24] referred that 
immobilize thermolysin by cross linking glutaraldehyde onto gold interdigitated microelectrodes was high stable during 30 days of storage at $4^{\circ} \mathrm{C}$ in $20 \mathrm{mM}$ phosphate buffer $\mathrm{pH} 7.0$. Furthermore, Nagayasu et al. [16] noticed that the immobilized enzyme on Amberlite XAD-7 was stable for over $300 \mathrm{~h}$ of usage at $45^{\circ} \mathrm{C}$ without any loss of activity.

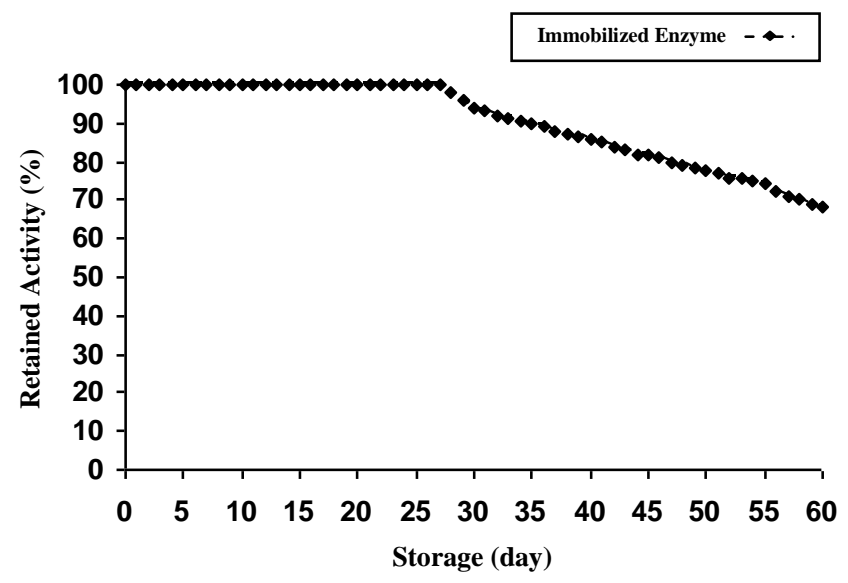

Figure 5- Effect of different period of storage at $4^{\circ} \mathrm{C}$ of immobilized thermolysin on bentonite.

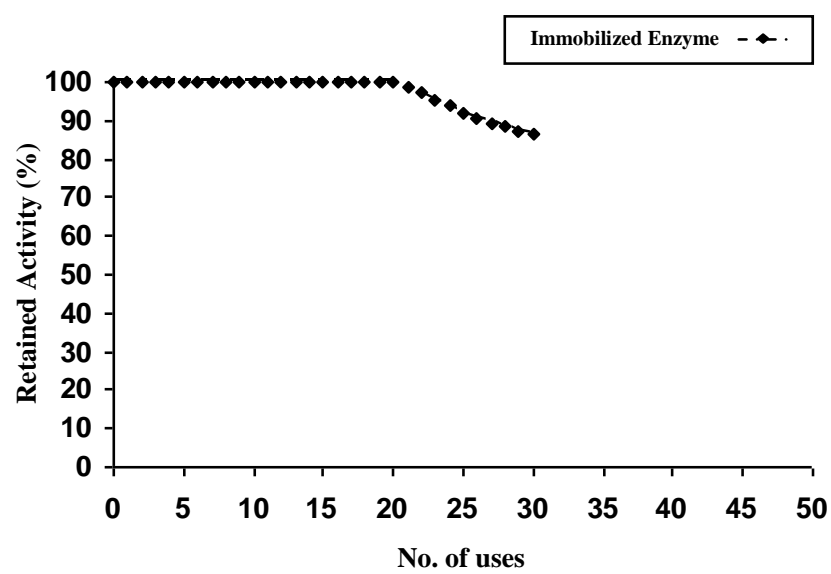

Figure 6- Effect of reuse of immobilized thermolysin on bentonite.

\section{Application}

The yield of aspartame precursor N-(B enzyloxycarbony1)-L-aspartyl-L-phenylalaninme ethyl ester (Z-AspPheOMe) was increased at the time of reaction (Figure-7). It was 9\% after $1 \mathrm{~h}$ and then increased gradually to be $100 \%$ after $10 \mathrm{~h}$ at reaction conditions.

Immobilized thermolysin was used for the production of aspartame precursor and it has others applications. The enzymatic synthesis method was preferred for commercial production of aspartame compared with chemical syntheses method because the reaction can be increased with high specificity and consequently give a high yield. In this context, Nagayasu et al. [16] prepared aspartame precursor by using immobilized thermolysin on Amberlite XAD-7 in fert-amyl alcohol. In addition, Miyanaga et al. [17] used immobilized thermolysin in Amberlite XAD-7 for synthesis of aspartame precursor in a mixed of tert-amyl alcohol (TA) and ethyl acetate (EA) at 33:67 (v/v), the reaction was at $40^{\circ} \mathrm{C}$ with a yield of $99 \%$ during 3.6h. While, Kusano et al. [3] used free thermolysin to synthesis of $\mathrm{N}$ carbobenzoxy-1-aspartyl-1-phenylalanine methyl ester (ZDFM), a precursor of aspartame. Whereas, Ogino et al. [25] developed the synthesis of aspartame precursor by using PST-01 protease and thermolysin, and mentioned that the rate of synthesis was slower than thermolysin as a substrate for production of aspartame precursor. 


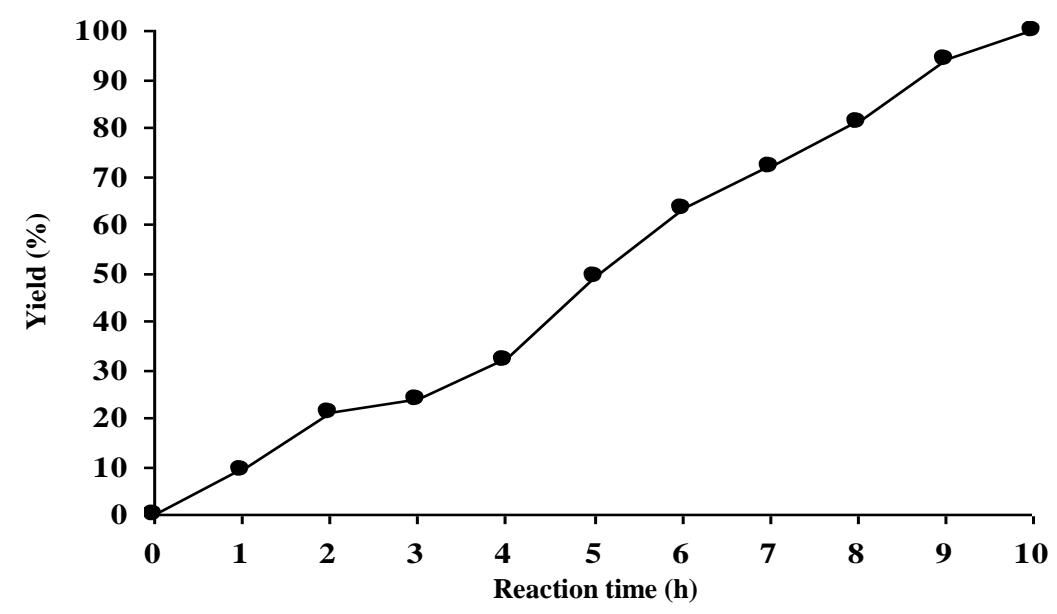

Figure 7- The yield of aspartame precursor by immobilized thermolysin on bentonite.

\section{References}

1. Di Bernardini R., Rai, D.K., Bolton, D., Kerry, J., O’Neill, E., Mullen, A.M., Harnedy, P. and Hayes, M. 2011. Isolation, purification and characterization of antioxidant peptidic fractions from a bovine liver sarcoplasmic protein thermolysin hydrolysate. Peptides, 32(2): 388-400. https://doi.org/10.1016/j.peptides.2010.11.024

2. David A.E., Gong, J., Chertok, B., Domszy, R.C., Moon, C., Park, Y.S., Wang, N.S., Yang, A.J. and Yang, V.C. 2012. Immobilized thermolysin for highly efficient production of low-molecularweight protamine-An attractive cell-penetrating peptide for macromolecular drug delivery applications, Journal of Biomedical Materials Research A. 100A(1): 211-219. https://doi.org/10.1002/jbm.a.33244

3. Kusano M., Yasukawa, K. and Inouye, K. 2010. Effects of the mutational combinations on the activity and stability of thermolysin. Journal of Biotechnology, 147(1, 3): 7-16.

https://doi.org/10.1016/j.jbiotec.2010.02.024

4. Chang L.C., Lee, H.F., Yang Z.Q. and Yang, V.C. 2001. Low molecular weight protamine (LMWP) as nontoxic heparin/low molecular weight heparin antidote (I): Preparation and characterization. AAPS Pharmsci, 3(3): 7-14. http://doi.org/10.1208/ps030317

5. Chen F., Zhang, F., Du, F., Wang, A., Gao, W., Wang, Q., Yin, X. and Xie, T. 2012. A novel and efficient method for the immobilization of thermolysin using sodium chloride salting-in and consecutive microwave irradiation. Bioresource Technology, 115: 158-163. http://doi.org/10.1016/j.biortech.2011.11.059

6. Alsoufi M.A., Aziz, R.A. and Hussein, Z.G. 2017. Effect of some artificial sweeteners consumption in biochemical parameters of rats. Current Research in Microbiology and Biotechnology, 5(3): 1095-1099. http://crmb.aizeonpublishers.net/content/2017/3/crmb1095-1099.pdf

7. Gupta S., Mahajan, V., Mahajan. S. and Tandon, V.R. 2012. Artificial sweeteners, JK Science, 14(1): 2-4. http://www.jkscience.org/archive/volume141/Artificial\%20Sweeteners.pdf

8. Fndkl Z. and Turkoglu, S. 2014. Determination of the effects of some artificial sweeteners on human peripheral lymphocytes using the comet assay. Journal of Toxicology and Environmental Health Sciences, 6(8): 147-153. https://doi.org/10.5897/JTEHS2014.0313

9. Al-Soufi, M.A. 2016. Quantitative and qualitative detection of vitamin C in some foods by immobilized ascorbate oxidase. International Journal of Sciences: Basic and Applied Research, 26(3): 235-245.

http://gssrr.org/index.php?journal=JournalOfBasicAndApplied\&page=article\&op=view\&path $\% 5$ $\mathrm{B} \% 5 \mathrm{D}=5623 \&$ path\%5B $\% 5 \mathrm{D}=2847$

10. Inouye K., Kusano, M., Hashida, Y., Minoda, M. and Yasukawa, K. 2007. Engineering, expression, purification, and production of recombinant thermolysin. Biotechnology Annual Review, 13: 43-64. https://doi.org/10.1016/S1387-2656(07)13003-9 
11. Alsoufi, M.A. 2018. Use of immobilized laccase in bioremediation of phenolic compounds which causes environmental pollution. Journal of Biodiversity and Environmental Sciences, 12(3): 370377. http://www. innspub.net/wp-content/uploads/2018/05/JBES-Vol-12-No-3-p-370-377.pdf

12. Datta S, Christena, L.R. and Rajaram, Y.R.S. 2013. Enzyme immobilization: an overview on techniques and support materials. 3 Biotech, 3: 1-9. http://doi.org/10.1007/s13205-012-0071-7

13. Al-Soufi M.A. 2015. Production of high fructose syrup by using invertase that immobilization on Iraqi bentonite. Thi-Qar University Journal for Agricultural Researches, 4(2): 202-215. https://www.iasj.net/iasj?func=article\&aId=120893

14. Bradford, M.M. 1976. A rapid and sensitive method for the quantitation of microgram quantities of protein utilizing the principle of protein-dye binding, Analytical Biochemistry, 72: 248-254. http://hoffman.cm.utexas.edu/courses/bradford assay.pdf

15. David, A.E. 2004. Immobilization of Enzymes on Nanoporous, Silica Composites. Doctor of Philosophy Theses, Faculty of the Graduate School, University of Maryland, College Park, USA. https://drum.lib.umd.edu/bitstream/handle/1903/2055/umi-umd-2016.pdf?sequence=1

16. Nagayasu T., Miyanaga, M., Tanaka, T., Sakiyama, T. and Nakanishi, K. 1994. Synthesis of aspartame precursor with an immobilized thermolysin in tert-amy1 alcohol. Biotechnology and Bioengineering, 43: 1118-1123. https://doi.org/10.1002/bit.260431116

17. Miyanaga M., Tanaka, T., Sakiyama, T. and Nakanishi, K. 1995. Synthesis of aspartame precursor with an immobilized thermolysin in mixed organic solvents. Biotechnology and Bioengineering, 46: 631-635. https://doi.org/10.1002/bit.260460617

18. Moeschel K., Nouaimi, M., Steinbrenner, C. and Bisswanger, H. 2003. Immobilization of thermolysin to polyamide nonwoven materials. Biotechnology and Bioengineering, 82(2): 190199. https://doi.org/10.1002/bit.10565

19. Mateo C., Palomo, J.M., Fernandez-Lorente, G., Guisan, J.M. and Fernandez-Lafuente, R. 2007. Improvement of enzyme activity, stability and selectivity via immobilization techniques. Enzyme and Microbial Technology, 40: 1451-1463. https://doi.org/10.1016/j.enzmictec.2007.01.018

20. Yun, S-E. 1988. Immobilization of thermolysin and application of the immobilized thermolysin to cheese-making. Korean Journal of Food Science and Technology, 20(2): 245-251. https://www.researchgate.net/profile/Sei_Eok_Yun/publication/263398846_Immobilization_of_Th ermolysin_and_Application_of_the_Immobilized_Thermolysin_to_Cheesemaking/links/5541c8160cf2322227317204/Immobilization-of-Thermolysin-and-Application-ofthe-Immobilized-Thermolysin-to-Cheese-making.pdf

21. Persichetti R.A., Clair, N.L.S., Griffith, J.P., Navia, M.A. and Margolin, A.L. 1995. Cross-linked enzyme crystals (CLECs) of thermolysin in the synthesis of peptides. Journal of American Chemical Society, 177: 2732-2737. https://doi.org/10.1021/ja00115a008

22. Belyaeva A.V., Smirnova, Yu.A., Lysogorskaya, E.N., Oksenoit, E.S., Timofeeva, A.V., Lozinskii, V.I. and Filippova, I.Yu. 2008. Biocatalytic properties of thermolysin immobilized on polyvinyl alcohol cryogel. Russian Journal of Bioorganic Chemistry, 34(4): 435-441. https://doi.org/10.1134/S1068162008040079

23. Dridi F., Marrakchi, M., Gargouri, M., Garcia-Cruz, A., Dzyadevych, S., Vocanson, F., Saulnier, J., Jaffrezic-Renault, N. and Lagarde, F. 2015a. Thermolysin entrapped in a gold nanoparticles/polymer composite for direct and sensitive conductometric biosensing of ochratoxin A in olive oil. Sensors and Actuators B: Chemical, 221: 480-490. https://doi.org/10.1016/j.snb.2015.06.120

24. Dridi F., Marrakchi, M., Gargouri, M., Saulnier, J., Jaffrezic-Renault, N. and Lagarde, F. 2015b. Comparison of carboxypeptidase $\mathrm{Y}$ and thermolysin for ochratoxin A electrochemical biosensing. Analytical Methods, 7: 8954-8960. https://doi.org/10.1039/C5AY01905B

25. Ogino H., Tsuchiyama1, S., Yasuda, M. and Doukyu, N. 2010. Enhancement of the aspartame precursor synthetic activity of an organic solvent-stable protease. Protein Engineering, Design \& Selection, 23(3): 147-152. https://doi.org/10.1093/protein/gzp086 